\title{
Influence of the reaction time on the quality (physical- chemical properties) of biofuels obtained through catalytic cracking of crude palm oil
}

Influência do tempo de reação sobre as propriedades físico-químicas de biocombustíveis obtidos através do craqueamento térmico catalítico do óleo de palma bruto

\author{
S. A. P. Mota ${ }^{1,2 *}$ A. A. Mancio'² J. S. Santanna'2; V. J. P. Gama²; N. T. Machado ${ }^{1,3}$

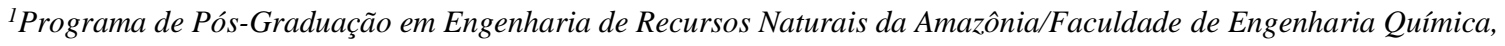 \\ Universidade Federal do Pará, 66075-110, Belém-PA, Brasil \\ ${ }^{2}$ Programa de Pós-Graduação em Química/Instituto de Ciencias Exatas, Universidade Federal do Sul e Sudeste do \\ Pará, 68505-080, Marabá-PA, Brasil \\ ${ }^{3}$ Faculdade de Engenharia Sanitária e Ambiental, Universidade Federal do Pará, 66075-110, Belém-PA, Brasil
}

*silviomota@unifesspa.edu.br

(Recebido em 19 de agosto de 2020; aceito em 14 de junho de 2021)

\begin{abstract}
The present paper investigated the influence of the reaction time on the quality (physical-chemical properties) of biofuels obtained by catalytic cracking of crude palm oil (CPO). The influence of the reaction time (10, $20,30,40,50$, and $60 \mathrm{~min}$ ) on the quality of crude biofuels denominated organic liquid products (OLP) was investigated through experiments carried out in a cracking pilot plant with capacity of $143 \mathrm{~L}$ in the following operating conditions: $20 \mathrm{wt} \%$ sodium carbonate $\left(\mathrm{Na}_{2} \mathrm{CO}_{3}\right)$ as catalyst, $450{ }^{\circ} \mathrm{C}, 1 \mathrm{~atm}$ and batch mode operation. The quality of the biofuels produced was certified through physical-chemical analyzes (acid value, saponification value, specific gravity, refractive index, kinematic viscosity, corrosiveness to copper, and flash point). The results show that the physical-chemical properties of OLP decrease as the reaction time increases, in such a way that, catalytic cracking process occurs efficiently in the interval of 10 to $20 \mathrm{~min}$ after its start, which can be finalized when it reaches 30 minutes of reaction. In addition, $\mathrm{Na}_{2} \mathrm{CO}_{3}$ was essential as a catalyst in the cracking reaction to reduce the physical-chemical properties of OLPs obtained at different times, allowing the specific gravity, kinematic viscosity and corrosivity to copper to be within or very close to the limits established for Diesel S10.
\end{abstract}

Keywords: Bio-oil, organic liquid product, pilot plant.

O presente trabalho investigou a influência do tempo de reação sobre a qualidade (propriedades físicoquímicas) de biocombustíveis obtidos por craqueamento térmico catalítico de óleo de palma bruto (OPB). A influência do tempo de reação $(10,20,30,40,50$ e $60 \mathrm{~min})$ sobre a qualidade dos biocombustíveis brutos denominados produtos orgânicos líquidos (PLO) foi investigada por meio de experimentos realizados em uma planta piloto de craqueamento com capacidade de $143 \mathrm{~L}$ nas seguintes condições operacionais: $20 \% \mathrm{em}$ massa de carbonato de sódio $\left(\mathrm{Na}_{2} \mathrm{CO}_{3}\right)$ como catalisador, $450{ }^{\circ} \mathrm{C}, 1 \mathrm{~atm}$ e operação em batelada. A qualidade dos biocombustíveis produzidos foi certificada através de análises físico-químicas (índice de acidez, índice de saponificação, massa específica, índice de refração, viscosidade cinemática, corrosividade ao cobre e ponto de fulgor). Os resultados mostram que as propriedades físico-químicas do PLO diminuem com o aumento do tempo de reação, de forma que o processo de craqueamento catalítico ocorre de forma eficiente no intervalo de 10 a 20 min após seu início, podendo ser finalizado quando atinge 30 minutos de reação. Além disso, o $\mathrm{Na}_{2} \mathrm{CO}_{3}$ foi essencial como catalisador na reação de craqueamento para redução das propriedades físico-químicas dos PLOs obtidos em diferentes tempos, permitindo que a gravidade específica, viscosidade cinemática e corrosividade ao cobre fique dentro ou muito próximos dos limites estabelecidos para Diesel S10.

Palavras-chave: Bio-óleo, produto líquido orgânico, planta piloto.

\section{INTRODUTION}

Currently, fossil fuels represent the primary sources of energy that have met the energy demand of modern society. However, limited reserves of fossil fuels and global warming make their use unsustainable and cause environmental problems related to their combustion due to the emission of large amounts of $\mathrm{CO}_{2}$ [1]. In this sense, environmentally friendly biofuels can be an alternative source of renewable and sustainable energy to meet the global energy demand for the transport 
sector [1,2], which is considered the second fastest growing sector concerning energy consumption [3].

Production of biofuels that are made up of hydrocarbons can be carried out by several different routes [4]. Catalytic cracking [5-21] is one of the routes that can be applied effectively to feedstocks based on triglycerides such as vegetable oils to produce hydrocarbons [22]. Catalytic cracking of vegetable oils can generate the following products: gaseous biofuels, including hydrocarbons $\mathrm{C} 1$ $\mathrm{C} 5, \mathrm{CO}$ and $\mathrm{CO}_{2}$; liquid biofuels, which are called bio-oil or organic liquid product (OLP); water and coke [23-26].

Several publications report the parameters that influence the catalytic cracking process of vegetable oils and the effect of these parameters on the yield and physical-chemical property values of OLP [11, 15-17, 22, 27-33]. Such parameters are temperature, reaction time, heating rate, gas flow rate, feed rate, particle size, presence of water, type of catalyst and biomass composition, among others [11, 15-17, 22, 27-33]. In parallel, the values of the physical properties of OLP are the result of its chemical composition [24], which in turn is dependent on the source of biomass and the operational conditions used in its production [28, 34, 35].

According to Chew and Bhatia (2008) [21], the temperature of the catalytic cracking process (in this case, $\left.450^{\circ} \mathrm{C}\right)$ is lower than the pyrolysis $\left(500-850^{\circ} \mathrm{C}\right)$. Idem et al. (1996) [36] have carried out the thermal cracking of canola oil, which was carried out in a fixed bed reactor in the presence and absence of steam, with the temperature between 300 and $500^{\circ} \mathrm{C}$ on atmospheric pressure, obtaining as a result a yield of 54\% (w/w) into Hydrocarbons. Dandik and Aksoy (1998) [37] evaluated the residual sunflower oil conversion by thermal catalytic cracking in the presence of acid catalysts and sodium carbonate, varying the temperature between 400 and $420^{\circ} \mathrm{C}$. The results of this study showed a yield of $32.8 \%(\mathrm{w} / \mathrm{w})$ of liquid hydrocarbons with the use of sodium carbonate and $420^{\circ} \mathrm{C}$. Li et al. (2009) [38] have carried out the thermal catalytic cracking of cottonseed oil in a reactor of fixed-fluidized bed and $1 \mathrm{~atm}$ using one zeolite as catalyst. The authors investigated the effect of temperature $\left(400-500^{\circ} \mathrm{C}\right)$, ratio catalyst/oil (6-10) and residence time (50-90s) on the yield of gasoline and diesel fractions. The results showed that the optimal condition for thermal catalytic cracking of cottonseed oil produce the highest yield of these fractions was: reaction temperature of $426.2^{\circ} \mathrm{C}$, ratio catalyst/oil of $7.8 \mathrm{~g} / \mathrm{g}$ and residence time of $50.2 \mathrm{~s}$, getting $65.6 \%(\mathrm{w} / \mathrm{w})$ of diesel fraction $\left(\leq 360^{\circ} \mathrm{C}\right)$ and $33.7 \%(\mathrm{w} / \mathrm{w})$ of gasoline fraction $\left(\leq 200^{\circ} \mathrm{C}\right)$ and a minimum yield of gas equal to $11.6 \%(\mathrm{w} / \mathrm{w})$.

Regarding the type of catalyst used in the catalytic cracking process, basic catalysts such as sodium carbonate $\left(\mathrm{Na}_{2} \mathrm{CO}_{3}\right)$ have been investigated in order to convert triglyceride-based feedstocks into biofuels with low carboxylic acid content [7, 19, 23, 31, 36-41]. Junming et al. (2009) [42] cracked soybean oil with basic catalysts $\left(\mathrm{Na}_{2} \mathrm{CO}_{3}, \mathrm{Al}_{2} \mathrm{O}_{3}, \mathrm{~K}_{2} \mathrm{CO}_{3}\right)$ in the temperature range of 350 to $400{ }^{\circ} \mathrm{C}$, obtaining biofuels with a diesel-like chemical composition, with low acid values and good cold flow properties. Weber et al. (2012) [43] performed the thermal degradation of free fatty acids and animal fat using $\mathrm{Na}_{2} \mathrm{CO}_{3}$ and $5 \mathrm{wt} \%$ water at $430 \pm 20{ }^{\circ} \mathrm{C}$ at a pilot plant. According to the results obtained Weber et al. (2012) [41], free fatty acids yielded 64-74 wt\% OLP with acid values ranging from 0.64 to $0.80 \mathrm{mg} \mathrm{KOH} / \mathrm{g}$, while animal fat yielded $60-70 \mathrm{wt} \%$ with acid values ranging from 0.5 to $1.8 \mathrm{mg} \mathrm{KOH} / \mathrm{g}$. Gas yields ranged from 25 to $30 \mathrm{wt} \%$ and coke yields from 4 to $6 \mathrm{wt} \%$.

As reported above, a series of studies have been carried out on the parameters that influence the catalytic cracking process of vegetable oils, as well as their effects on the yield and quality of biofuels. However, few studies have investigated the effect of reaction time on the quality of organic liquid products. Hew et al. (2010) [15] made improvements in the OLP by catalytic cracking to mainly produce gasoline and showed that OLP yield decreases with the reaction time. In contrast, gasoline yield increases as reaction time increase from 0.5 to $15 \mathrm{~min}$ and decreases slightly as reaction time increases to $30 \mathrm{~min}$. In parallel, as the reaction progresses, it is possible to convert more OLP into gasoline. Sousa et al. (2018) [44] performed simultaneous deoxygenation, cracking, and isomerization reactions of a fatty material with $1.5 \mathrm{~g}$ of the Hbeta catalyst. Operating conditions of these reactions can be summarized as follows: reaction time ( 5 to $10 \mathrm{~h}$ ), temperature ( 300 to $\left.350{ }^{\circ} \mathrm{C}\right)$, initial pressure of $\mathrm{H}_{2}(10 \mathrm{bar})$ and agitation $(800 \mathrm{rpm})$. According to the results obtained by Sousa et al. (2018) [44] there was a decrease in hydrocarbon content with increasing 
reaction time and a significant increase in gas content with increasing reaction time $(68 \%$ after $7 \mathrm{~h}$ and $90 \%$ after $12 \mathrm{~h}$ ), resulting in the reduction of liquid hydrocarbons.

In this context, the main objective of the present study is to investigate the influence of reaction time on the quality (physical-chemical properties) of the OLP obtained via the catalytic cracking process of crude palm oil (CPO) in a cracking pilot plant with capacity of $143 \mathrm{~L}$ in the following operating conditions: $20 \mathrm{wt} \%$ sodium carbonate $\left(\mathrm{Na}_{2} \mathrm{CO}_{3}\right)$ as catalyst, $450{ }^{\circ} \mathrm{C}, 1 \mathrm{~atm}$ and batch mode operation.

\section{MATERIAL AND METHODS}

\subsection{Crude palm oil}

Crude palm oil (Elaeis guineensis Jacq.) was provided by Engefar Ltda (Ananindeua-ParáBrazil). The crude palm oil (CPO) has been physical-chemically characterized as described in the literature [19]. To be used in catalytic cracking experiments, the CPO did not undergo any treatment.

\subsection{Catalyst}

The fresh Sodium Carbonate $\left(\mathrm{Na}_{2} \mathrm{CO}_{3}\right)$, commercial soda ASH Light (D50), with a purity of $98.0 \mathrm{wt} \%$ were the catalysts used in this work. Solvay Chemicals International SA (Brussels, Belgium) supplied sodium carbonate.

\subsection{Thermal cracking}

For purposes of comparison with the results of catalytic cracking, a thermal cracking experiment was carried out on a semi-pilot scale. The methodology for this experiment consisted of weighing $785 \mathrm{~g}$ of CPO. Then, the CPO was introduced in a reactor made of stainless steel with mechanical agitation and a capacity of $2 \mathrm{~L}$. The reactor was coupled to the semi-pilot plant, and then it was surrounded by an electrical resistance associated with a blanket made of insulating material (glass wool), in order to maintain the heating of the reaction system with the least possible loss of heat to the environment. The cracking temperature was programmed to $450^{\circ} \mathrm{C}$, with a heating rate of 10 ${ }^{\circ} \mathrm{C} / \mathrm{min}$, under constant agitation of $750 \mathrm{rpm}$ and under nitrogen flow from $0.02 \mathrm{ml} / \mathrm{min}$ to 0.04 $\mathrm{ml} / \mathrm{min}$. The vapors formed within the reaction system were condensed and collected in a collection vessel. Once obtained, the OLP was subjected to a simple filtration process to remove particulate matter (catalyst and solid waste). Subsequently, the OLP was subjected to physical-chemical analyzes, as described in Section 2.6.

\subsection{Catalytic cracking}

The experimental apparatus used in performing this work was a cracking pilot plant, which consists of the following systems: feed, pre-heater, sludge bed reactor, mechanical agitation (impeller), GLP burning (heating), OLP condensation, combustion gas exhaust, water recirculation and cooling, OLP collection, gas flare, and control unit. The central equipment is the sludge bed reactor of carbon stainless steel with a capacity of 143 L. Mota et al. (2014) [19] describe in detail the pilot plant used in this study.

The experimental procedure of the catalytic cracking of crude palm oil to obtain Organic Liquid Product was performed as described by da Mota et al. (2014) [19] under the following conditions: $450^{\circ} \mathrm{C}, 1 \mathrm{~atm}$ and $20 \mathrm{wt} \%$ of sodium carbonate as the catalyst. Basically, $50 \mathrm{~kg}$ of CPO were weighed, as well as the catalyst was weighed ( $20 \%$ by weight of CPO). Then, the catalyst was introduced into the reactor, while the CPO was stored in the polyethylene tank, and subsequently pumped to the sludge bed reactor, flowing through the pre-heater, in order to increase the CPO 
temperature to $200^{\circ} \mathrm{C}$ and thus be able to enter the reactor. The sludge bed reactor is heated to $450^{\circ} \mathrm{C}$ and the mechanical impeller was set to $150 \mathrm{rpm}$. When the reaction time of the cracking process reached $30 \mathrm{~min}$, the formation of non-condensable gases was observed in the gas flare. As the amount of gases generated in the catalytic cracking reaction increases, flowing through the condenser, part of this mixture of hydrocarbons called organic liquid product was collected in a collection vessel made of stainless steel. After the reaction time of the cracking process reached 60 min, the production of the OLP was completed, as no more OLP could be collected, meaning that all the CPO has been cracked.

\subsection{Evaluation of reaction time}

During the experimental procedure of catalytic cracking, there was a parallel study to evaluate the influence of reaction time on the quality of OLP. Thus, the experimental procedure consists in collecting samples OLP (Figure 1) at different reaction times (10, 20, 30, 40, 50, and 60 minutes) during crude palm oil cracking. Then, the OLP samples were adequately stored in $1000 \mathrm{ml}$ glass bottles and amber color. Finally, the OLP containing the mixture of all OLP obtained at different reaction times were stored in a polyethylene container of $50 \mathrm{~L}$.

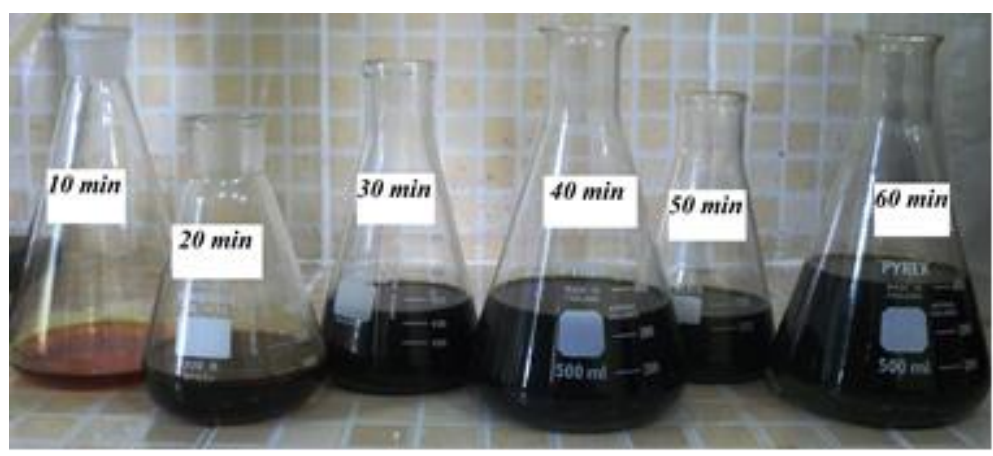

Figure 1: OLP samples at different reaction times.

\subsection{Characterization of the OLP}

OLP has been physical-chemically characterized according to AOCS and ASTM official methods for Acid Value (AOCS Cd 3d-63), Saponification Value (AOCS Cd 3-25), Specific Gravity at $20^{\circ} \mathrm{C}$ (ASTM D854), Refractive Index (AOCS Cc 7-25), Kinematics Viscosity at $40{ }^{\circ} \mathrm{C}$ (ASTM 446 and ASTM D2515), Flash Point (ASTM D93), and Corrosiveness to Copper (ASTM D130).

\section{RESULTS AND DISCUSSION}

\subsection{Thermal cracking}

According to Table 1, the OLP obtained from the thermal cracking of the CPO showed high values of acidity index and kinematic viscosity. On the other hand, the values of specific mass, flash point and corrosivity to copper were within the limits established for Diesel S10, according to ANP $\mathrm{N}^{\circ} 65$ [45]. A more detailed analysis of the results listed in the Table 1 is presented in Section 3.2 when comparing them with the results of the catalytic cracking of CPO. 
Table 1: Physical-chemical properties of the OLP obtained from the thermal cracking of CPO.

\begin{tabular}{lcc}
\hline \multicolumn{1}{c}{ Physical-chemical properties } & OLP & Diesel S10/ANP N $\mathbf{~ 6 5 ~ [ 4 5 ] ~}^{\circ}$ \\
\hline Specific gravity at $\mathbf{2 0}{ }^{\circ} \mathbf{C ~}\left(\mathbf{k g} / \mathbf{m}^{\mathbf{3}}\right)$ & 850 & $820-880$ \\
Kinematic viscosity at $\mathbf{4 0}{ }^{\circ} \mathbf{C ~}\left(\mathbf{m m}^{2} / \mathbf{s}\right)$ & 10.76 & $2.0-4.5$ \\
Acid value $(\mathbf{m g ~} \mathbf{K O H} / \mathbf{g})$ & 151.19 & 0.50 \\
Saponification value $(\mathbf{m g ~ K O H} / \mathbf{g})$ & 292.11 & - \\
Flash point $\left({ }^{\circ} \mathbf{C}\right)$ & 38.00 & $\geq 38$ \\
Corrosiveness to Copper. $\mathbf{3 h}$ at $\mathbf{5 0}{ }^{\circ} \mathbf{C}$ & $1 \mathrm{~A}$ & $1 \mathrm{~A}$ \\
\hline
\end{tabular}

\subsection{Catalytic Cracking}

In Figures 2, 3, 4, and 5, the reaction time significantly influenced the values of physicalchemical properties (specific gravity, kinematic viscosity, acid value, saponification value and flash point) of the OLP during cracking crude palm oil. Through the operational conditions adopted in this study, as the reaction time increased from 0 to $60 \mathrm{~min}$, these physical-chemical properties reduced sharply. This fact can be explained by the breakdown of CPO molecules due to prolonged exposure to high temperatures and the effect of the catalyst, resulting in products with lower molecular weight than CPO. Zhao et al. (2015) [11] investigated the catalytic cracking of carinata oil in a continuous flow fixed-bed reactor at $450{ }^{\circ} \mathrm{C}$, with a nominal residence time of approximately $60 \mathrm{~min}$. The results show that carinata oil was converted to hydrocarbons with molecules smaller than those of crude carinata oil, which resulted in lower density and viscosity of the biofuel. Mancio et al. (2016) [7] found that an increase in light hydrocarbon fractions caused a decrease in both the specific gravity values at $20^{\circ} \mathrm{C}$ and the kinematic viscosity values.

According to Table 1, and Figures 2, 3, 4, and 5 the OLPs obtained in several times from the catalytic cracking of the CPO showed acid value and flash point values higher than that established for the Diesel S10. On the other hand, the values of specific gravity, kinematic viscosity and corrosivity to copper are within or very close to the lower limits established for Diesel S10, according to ANP $\mathrm{N}^{\circ} 65$.

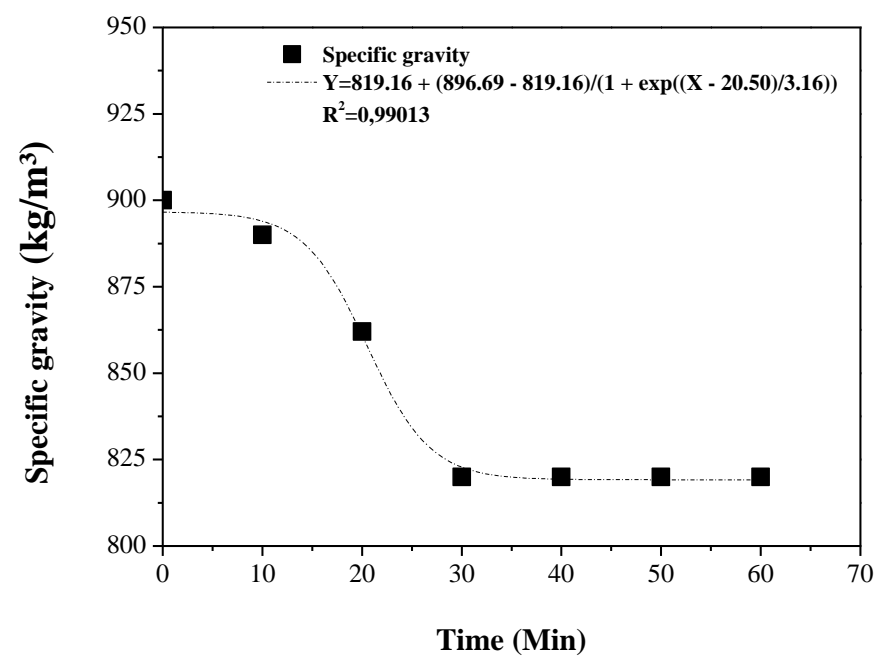

Figure 2: Specific gravity at $20^{\circ} \mathrm{C}$ of OLP samples as a function of reaction time.

Figures 2, 3, 4, and 5 also show that most physical-chemical properties of OLPs significantly reduced between 10 and 30 min of cracking, remaining practically constant from $30 \mathrm{~min}$. The reaction time is the primary factor to ensure a catalytic process efficiently [43]. If the reaction time exceeds the optimum time, the majority of the components present in the liquid products will further decompose into other low molecular weight products [15]. It is added to this the fact that the longer the reaction time, the higher the process cost [44]. 


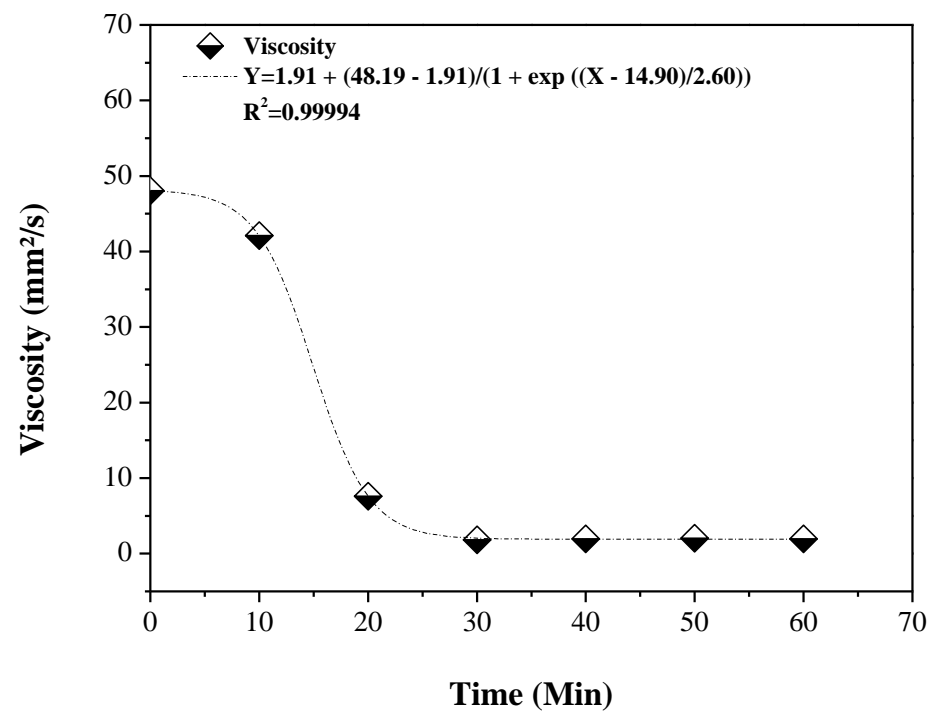

Figure 3: Kinematic viscosity at $40{ }^{\circ} \mathrm{C}$ of OLP samples as a function of reaction time.

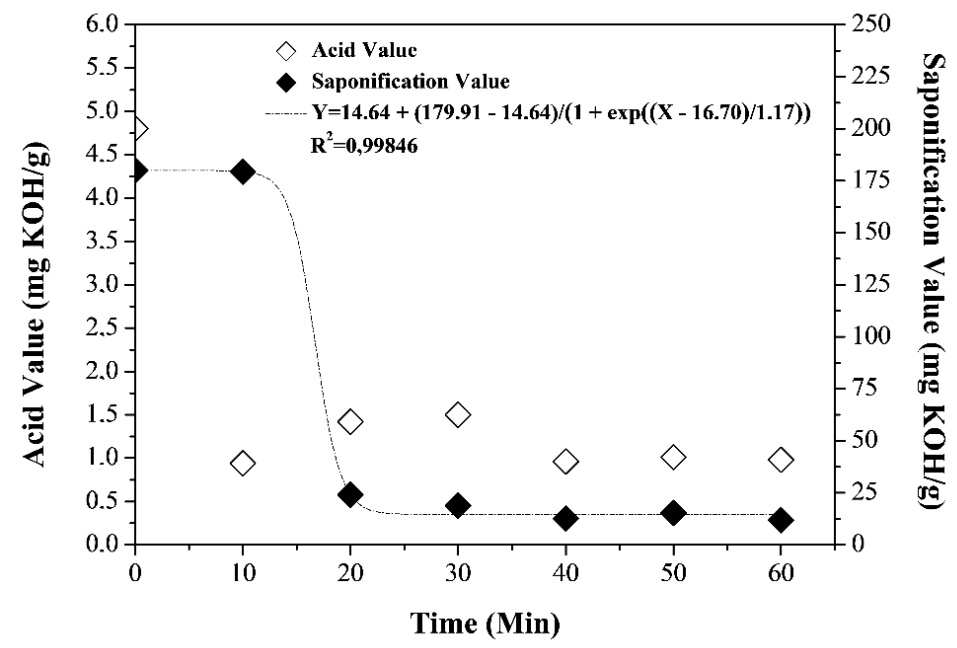

Figure 4: Acid value and saponification value of OLP samples as a function of reaction time.

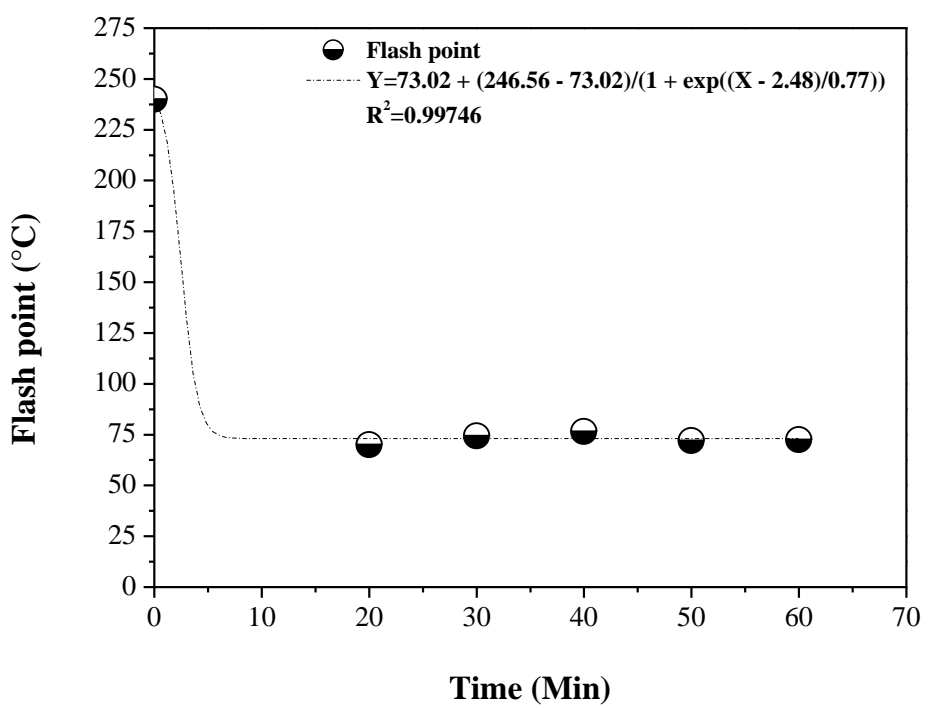

Figure 5: Flash point of OLP samples as a function of reaction time. 
A more detailed analysis of Figure 4 shows that the carboxylic acids (free fatty acids) present in the crude palm oil underwent a deoxygenation process in the period of 0 to $10 \mathrm{~min}$ of reaction, resulting in a significant reduction of the acid value in the first 10 min. Comparing the results presented in Figure 4 for catalytic cracking with those in Table 1 for thermal cracking, the reduction in the acid value of the OLP is due to the direct and immediate influence of the use of $20 \mathrm{wt} \%$ of sodium carbonate. In fact, sodium carbonate has a significant effect on the deoxygenation stage of the carboxylic acids. causing a significant reduction in the content of oxygenated compounds (especially carboxylic acids) or acid phase, consequently reducing the acid value of OLP [7, 38]. Between 10 and $40 \mathrm{~min}$ of reaction, the values of acid value presented a small variation and did not exceed $1.5 \mathrm{mg} \mathrm{KOH} / \mathrm{g}$, remaining constant from $40 \mathrm{~min}$. This small variation is due to the breakdown of the crude palm oil molecules and subsequently formation of compounds with predominance of carboxyls [23, 46-49]. resulting in a slight increase in the OLP acid value.

In parallel, Figure 4 also shows that in the first 10 min of reaction there was no significant change in the values of saponification value. Differently, in the period of 10 to $20 \mathrm{~min}$, there was a significant reduction of the saponification value, which did not show significant alterations after 20 min of cracking. According to Canapi et al. (2005) [48], the saponification value is the number of milligrams of potassium hydroxide required to neutralize the free fatty acid and saponify the esters in one gram of fat. In other words, the saponification value informs the presence of carboxylic acids in the form of free fatty acids and bound fatty acids, i.e., in the form of esters. Therefore, we can say that there was a reaction of cracking (primary cracking followed by secondary cracking) of palm oil in the period of 10 to $20 \mathrm{~min}$ of reaction. promoting a significant reduction of the saponification value in that period. According to Vonghia et al. (1995) [49], Katikaneni et al. (1995) [50], Idem et al. (1996) [36], Leng et al. (1999) [51], and Taufiqurrahmi \& Bhatia (2011) [23], the triglyceride molecules undergo a thermal cracking on the surface of the catalyst to form hydrocarbons and oxygenated compounds such as fatty acids, ketones, aldehydes and esters, characterizing the primary cracking. Thus, these compounds are converted by secondary cracking in gaseous products, paraffin, and olefins of long and short chains, $\mathrm{CO}, \mathrm{CO}_{2}$, water and alcohols, resulting in deoxygenation of oxygenated compounds, particularly, carboxylic acids.

According to Table 1 and Figure 5, for the OLP from catalytic cracking, the flash point value was higher than that established by the ANP $\mathrm{N}^{\circ} 65$. This fact is due to the presence of high molecular weight compounds, resulting in a value higher flash point for this OLP. The flash point indicates the presence of volatile components in the oil and is used to evaluate the overall flammability hazard of a material. The lower the flash point, the higher the concentration of light hydrocarbons in the material [52].

Table 2 shows that there were significant changes in the values of refractive index (RI) and that there were no changes in the values of corrosiveness to copper of the OLP during the $60 \mathrm{~min}$ of catalytic cracking. The lowest refractive index value was reached at 20 minutes of reaction, becoming a more physical-chemical property of OLP considered an indication that in the interval of 10 to 20 min there was a useful cracking reaction of CPO in molecules smaller when compared to the size of the molecules of the feedstock. According to Swern (1964) [53], one of the general relations between the refractive index and the composition of an oil-based product, with minor exceptions, is that the refractive index increases as the length of the carbon chain increases. From the $20 \mathrm{~min}$ of reaction, there was a gradual increase of the refractive index. without exceeding the value of the refractive index of palm CPO (RI = 1.46). as explained by da Mota et al. (2014) [19], indicating that there were at least oligomerization reactions of the products formed during the cracking process. According to Ong and Bhatia (2010) [54], light alkenes can undergo oligomerization to produce a mixture of alkenes and heavier alkanes. which are arranged under the fractions of gasoline, kerosene, and diesel.

As in the present paper, in previous works such as the work of Mancio et al. (2016) [7] and Mota et al. (2014) [19], the catalytic cracking of CPO was investigated, using sodium carbonate as a catalyst in a pilot cracking plant. However, the main difference of the present work in relation to the work of Mancio et al. (2016) [7] and da Mota et al. (2014) [19] is the study of the influence of reaction time on the physical-chemical properties of OLPs, in such a way that, from the present study it is possible to answer when the cracking reactions start, as well as the moment in which the 
physical-chemical properties no longer change as the cracking time progresses. Therefore, the results presented are relevant to the scientific community in the area.

Table 2: Refractive index and corrosiveness to copper of the OLP collected at different times during the catalytic cracking experiment of crude palm oil.

\begin{tabular}{lccccccc}
\hline \multirow{2}{*}{ Physical-chemical properties } & \multicolumn{7}{c}{ Time (Min) } \\
\cline { 2 - 8 } & $\mathbf{1 0}$ & $\mathbf{2 0}$ & $\mathbf{3 0}$ & $\mathbf{4 0}$ & $\mathbf{5 0}$ & $\mathbf{6 0}$ \\
\hline Refractive Index & 1.46 & 1.42 & 1.44 & 1.44 & 1.45 & 1.45 \\
Corrosiveness to Copper, $3 \mathbf{3 h}$ at $\mathbf{5 0}{ }^{\circ} \mathbf{C}$ & - & $1 \mathrm{~A}$ & $1 \mathrm{~A}$ & $1 \mathrm{~A}$ & $1 \mathrm{~A}$ & $1 \mathrm{~A}$ \\
\hline
\end{tabular}

\section{CONCLUSION}

From the present study, which investigated the influence of reaction time $(10,20,30,40,50$, and $60 \mathrm{~min}$ ) on the physical-chemical properties of OLP via catalytic cracking of crude palm oil with $20 \mathrm{wt} \% \mathrm{Na}_{2} \mathrm{CO}_{3}$ in a cracking pilot plant $(143 \mathrm{~L})$, it was concluded that: 1) reaction time significantly influenced the values of physical-chemical properties (specific gravity, kinematic viscosity, acid value, saponification value and flash point) of the OLP during cracking crude palm oil. As the reaction time increased from 0 to $60 \mathrm{~min}$, these physical-chemical properties reduced sharply; 2) thermal catalytic cracking process occurs efficiently in the interval of 10 to 20 min after its start, which can be finalized when it reaches 30 minutes of reaction. 3) sodium carbonate was essential as a catalyst in the cracking reaction for reducing the acid value of the OLPs obtained in several times, as well as for framing the values of specific gravity, kinematic viscosity and corrosivity to copper within or very close to the lower limits established for Diesel S10.

\section{ACKNOWLEDGEMENTS}

This work was financially supported by the Brazilian governmental agencies (CAPES and Eletrobrás S/A).

\section{REFERENCES}

1. Rodionova MV, Poudyal RS, Tiwari I, Voloshin RA, Zharmukhamedov SK, Nam HG, et al. Biofuel production: Challenges and opportunities. Int J Hydrogen Energy. 2017;42(12):8450-61, doi: 10.1016/j.ijhydene.2016.11.125.

2. Serrano-Ruiz JC, Dumesic JA. Catalysis for alternative energy generation. In: Guczi L, Erdôhelyi A, editors. Catalysis for alternative energy generation. 1st ed. New York (US): Springer; 2012. 536 p.

3. Industry Market trends. The damage done in transportation - which energy source will lead to the greenest highways? Thomas [Internet]; 2012 Apr 30 [accessed 2018 May 15]. Available from: https://www.thomasnet.com/insights/imt/2012/04/30/the-damage-done-in-transportation-which-energysource-will-lead-to-the-greenest-highways

4. Chiaramonti D, Prussi M, Buffi M, Tacconi D. Sustainable bio kerosene: Process routes and industrial demonstration activities in aviation biofuels. Appl Energy. 2014;136:767-74, doi: 10.1016/j.apenergy.2014.08.065.

5. Yu F, Gao L, Wang W, Zhang G, Ji J. Bio-fuel production from the catalytic pyrolysis of soybean oil over Me-Al-MCM-41 (Me=La. Ni or Fe) mesoporous materials. J Anal Appl Pyrolysis. 2013;104:325-9, doi: 10.1016/j.jaap.2013.06.017.

6. Teixeira CM, Fréty R, Barbosa CBM, Santos MR, Bruce ED, Pacheco JGA. Mo influence on the kinetics of jatropha oil cracking over Mo/HZSM-5 catalysts. Catal Today. 2017;279(Part 2):202-8, doi: 10.1016/j.cattod.2016.06.006.

7. Mancio AA, da Costa KMB, Ferreira CC, Santos MC, Lhamas DEL, da Mota SAP, et al. Thermal catalytic cracking of crude palm oil at pilot scale: Effect of the percentage of $\mathrm{Na} 2 \mathrm{CO} 3$ on the quality of biofuels. Ind Crops Prod. 2016;91:32-43, doi: 10.1016/j.indcrop.2016.06.033. 
8. da Silva Almeida H, Correa OA, Eid JG, Ribeiro HJ, de Castro DR, Pereira MS, et al. Production of biofuels by thermal catalytic cracking of scum from grease traps in pilot scale. J Anal Appl Pyrolysis. 2016;118:20-33, doi: 10.1016/j.jaap.2015.12.019.

9. Abbasov V, Mammadova T, Aliyeva N, Abbasov M, Movsumov N, Joshi A, et al. Catalytic cracking of vegetable oils and vacuum gasoil with commercial high alumina zeolite and halloysite nanotubes for biofuel production. Fuel. 2016;181:55-63, doi: 10.1016/j.fuel.2016.04.088.

10. Lovás P, Hudec P, Hadvinová M, Ház A. Conversion of rapeseed oil via catalytic cracking: Effect of the ZSM-5 catalyst on the deoxygenation process. Fuel Processing Tech. 2015;134:223-30, doi: 10.1016/j.fuproc.2015.01.038.

11. Zhao XH, Wei L, Cheng SY, Cao YH, Julson J, Gu ZR. Catalytic cracking of carinata oil for hydrocarbon biofuel over fresh and regenerated Zn/Na-ZSM-5. Appl Catal a-General. 2015;507:44-55, doi: 10.1016/j.apcata.2015.09.031.

12. Biswas S, Sharma DK. Effect of different catalysts on the cracking of Jatropha oil. J Anal Appl Pyrolysis. 2014;110:346-52, doi: 10.1016/j.jaap.2014.10.001.

13. Xu JM, Jiang JC, Zhang TJ, Dai WD. Biofuel Production from catalytic cracking of triglyceride materials followed by an esterification reaction in a scale-up reactor. Energy \& Fuels. 2013;27(1):255-61, doi: 10.1021/ef3018173.

14. Wang S, Guo Z, Cai Q, Guo L. Catalytic conversion of carboxylic acids in bio-oil for liquid hydrocarbons production. Biomass Bioenergy. 2012;45:138-43, doi: 10.1016/j.biombioe.2012.05.023.

15. Hew KL, Tamidi AM, Yusup S, Lee KT, Ahmad MM. Catalytic cracking of bio-oil to organic liquid product (OLP). Bioresource Tech. 2010;101(22):8855-8. doi;10.1016/j.biortech.2010.05.036.

16. Wu X, Jiang P, Jin F, Liu J, Zhang Y, Zhu L, et al. Production of jet fuel range biofuels by catalytic transformation of triglycerides based oils. Fuel. 2017;188:205-11, doi: 10.1016/j.fuel.2016.10.030.

17. Li L, Quan K, Xu J, Liu F, Liu S, Yu S, et al. Liquid hydrocarbon fuels from catalytic cracking of waste cooking oils using basic mesoporous molecular sieves K2O/Ba-MCM-41 as catalysts. ACS Sustainable Chem Eng. 2013;1(11):1412-6, doi: 10.1021/sc4001548.

18. Dandik L, Aksoy HA, Erdem-Senatalar A. Catalytic conversion of used oil to hydrocarbon fuels in a fractionating pyrolysis reactor. Energy \& Fuels. 1998;12(6):1148-52, doi: 10.1021/ef980012u.

19. da Mota SAP, Mancio AA, Lhamas DEL, de Abreu DH, da Silva MS, dos Santos WG, et al. Production of green diesel by thermal catalytic cracking of crude palm oil (Elaeis guineensis Jacq) in a pilot plant. J Anal Appl Pyrolysis. 2014;110(1), doi: 10.1016/j.jaap.2014.06.011.

20. Yigezu ZD, Muthukumar K. Biofuel production by catalytic cracking of sunflower oil using vanadium pentoxide. J Anal Appl Pyrolysis. 2015;112:341-7, doi: 10.1016/j.jaap.2015.01.002.

21. Chew TL, Bhatia S. Effect of catalyst additives on the production of biofuels from palm oil cracking in a transport riser reactor. Bioresource Tech. 2009;100(9):2540-5, doi: 10.1016/j.biortech.2008.12.021.

22. Chiaramonti D, Buffi M, Rizzo AM, Lotti G, Prussi M. Bio-hydrocarbons through catalytic pyrolysis of used cooking oils and fatty acids for sustainable jet and road fuel production. Biomass Bioenergy. 2016;95:424-3, doi: 10.1016/j.biombioe.2016.05.035.

23. Taufiqurrahmi N, Bhatia S. Catalytic cracking of edible and non-edible oils for the production of biofuels. Energy Environ Sci. 2011;4(4):1087-112, doi: 10.1039/c0ee00460j.

24. Yan S, DiMaggio C, Wang H, Mohan S, Kim M, Yang L, et al. Catalytic conversion of triglycerides to liquid biofuels through transesterification. cracking. and hydrotreatment processes. Curr Catal. 2012;1(1):41-51

25. Melero JA, García A, Clavero M. Production of biofuels via catalytic cracking. In: Handbook of Biofuels Production [Internet]. Woodhead Publishing; 2011. p. 390-419, doi: 10.1533/9780857090492.3.390.

26. Wiggers VR, Wisniewski A, Madureira LAS, Barros AAC, Meier HF. Biofuels from waste fish oil pyrolysis: Continuous production in a pilot plant. Fuel. 2009;88(11):2135-41, doi: 10.1016/j.fuel.2009.02.006.

27. Seifi H, Sadrameli SM. Improvement of renewable transportation fuel properties by deoxygenation process using thermal and catalytic cracking of triglycerides and their methyl esters. Appl Thermal Eng. 2016;100:1102-10, doi: 10.1016/j.applthermaleng.2016.02.022.

28. Wiggers VR, Zonta GR, Franca AP, Scharf DR, Simionatto EL, Ender L, et al. Challenges associated with choosing operational conditions for triglyceride thermal cracking aiming to improve biofuel quality. Fuel. 2013;107:601-8, doi: 10.1016/j.fuel.2012.11.011.

29. Stedile T, Ender L, Meier HF, Simionatto EL, Wiggers VR. Comparison between physical properties and chemical composition of bio-oils derived from lignocellulose and triglyceride sources. Renewable Sustainable Energy Rev. 2015;50:92-108, doi: 10.1016/j.rser.2015.04.080.

30. Lu Q, Li W-Z, Zhu X-F. Overview of fuel properties of biomass fast pyrolysis oils. Energy Conversion Manag. 2009;50(5):1376-83, doi: 10.1016/j.enconman.2009.01.001. 
31. Mâncio AA, da Costa KMB, Ferreira CC, Santos MC, Lhamas DEL, da Mota SAP, et al. Process analysis of physicochemical properties and chemical composition of organic liquid products obtained by thermochemical conversion of palm oil. J Anal Appl Pyrolysis. 2017;123:284-295, doi: 10.1016/j.jaap.2016.11.017.

32. Qiang L, Xu-Lai Y, Xi-Feng Z. Analysis on chemical and physical properties of bio-oil pyrolyzed from rice husk. J Anal Appl Pyrolysis. 2008;82(2):191-8, doi: 10.1016/j.jaap.2008.03.003.

33. Guedes RE, Luna AS, Torres AR. Operating parameters for bio-oil production in biomass pyrolysis: A review. J Anal Appl Pyrolysis. 2018;129:134-49, doi: 10.1016/j.jaap.2017.11.019.

34. Maher KD, Bressler DC. Pyrolysis of triglyceride materials for the production of renewable fuels and chemicals. Bioresource Tech. 2007;98(12):2351-68, doi: 10.1016/j.biortech.2006.10.025.

35. Wang S. High-Efficiency Separation of Bio-Oil. 2013; doi: 10.5772/51423. Wang S. High-efficiency separation of bio-oil. In: Matovic MD, editor. Biomass now - sustainable growth and use. [place unknown]: IntechOpen; 2013. p. 401-18, doi: 10.5772/51423.

36. Idem RO, Katikaneni SPR, Bakhshi NN. Thermal cracking of canola oil: Reaction products in the presence and absence of steam. Energy Fuels. 1996;10(6):1150-62, doi:10.1021/ef960029h.

37. Dandik L, Aksoy HA. Pyrolysis of used sunflower oil in the presence of sodium carbonate by using fractionating pyrolysis reactor. Fuel Processing Tech. 1998;57:81-92.

38. Li H, Shen B, Kabalu JC, Nchare M. Enhancing the production of biofuels from cottonseed oil by fixedfluidized bed catalytic cracking. Renew Energy. 2009;34(4):1033-9.

39. Konwer D, Taylor SE, Gordon BE, Otvos JW, Calvin M. Liquid fuels from Mesua ferrea L. Seed Oil. 1989;66(2):223-6, doi: 10.1007/BF02546064.

40. Zaher FA, Taman AR. Thermally decomposed cottonseed oil as a diesel-engine fuel. Energy Sources. 1993;15(3):499-504, doi: 10.1080/00908319308909042.

41. Dandik L, Aksoy HA. Effect of catalyst on the pyrolysis of used oil carried out in a fractionating pyrolysis reactor. Renew Energy. 1999;16(1):1007-10, doi: 10.1016/S0960-1481(98)00355-3.

42. Junming X, Jianchun J, Yanju L, Jie C. Liquid hydrocarbon fuels obtained by the pyrolysis of soybean oils. Bioresour Technol. 2009;100(20):4867-70, doi: 10.1016/j.biortech.2009.04.055.

43. Weber B, Stadlbauer EA, Stengl S, Hossain M, Frank A, Steffens D, et al. Production of hydrocarbons from fatty acids and animal fat in the presence of water and sodium carbonate: Reactor performance and fuel properties. Fuel. 2012;94:262-9, doi: 10.1016/j.fuel.2011.08.040.

44. Sousa FP, Silva LN, de Rezende DB, de Oliveira LCA, Pasa VMD. Simultaneous deoxygenation. cracking and isomerization of palm kernel oil and palm olein over beta zeolite to produce biogasoline. green diesel and biojet-fuel. Fuel. 2018;223:149-56, doi: 10.1016/j.fuel.2018.03.020.

45. Agência Nacional de Petróleo, Gás Natural e Biocombustíveis - ANP. Resolucão n ${ }^{\circ} 65$ de 01 de dezembro de 2009. Diário Oficial da União.12 dez 2011;237(Seção 1):195.

46. Zhang S, Yan Y, Li T, Ren Z. Upgrading of liquid fuel from the pyrolysis of biomass. Bioresour Technol. 2005;96(5):545-50, doi: 10.1016/j.biortech.2004.06.015.

47. Abnisa F, Daud WMAW, Husin WNW, Sahu JN. Utilization possibilities of palm shell as a source of biomass energy in Malaysia by producing bio-oil in pyrolysis process. Biomass Bioenergy. 2011;35(5):1863-72, doi: 10.1016/j.biombioe.2011.01.033.

48. Canapi EC, Agustin YTV, Moro EA, Pedrosa Jr E, Bendaño MLJ. Coconut oil. In: Shahidi F, editor. Bailey's industrial oil and fat products. Vol 2 - Edible oil and fat products: edible oils. 6th ed. New Jersey (US): John Wiley \& Sons, Inc.; 2005. p. 75.

49. Vonghia E, Boocock DGB, Konar SK, Leung A. Pathways for the deoxygenation of triglycerides to aliphatic hydrocarbons over activated alumina. Energy Fuels. 1995;9(6):1090-6, doi: 10.1021/ef00054a024.

50. Katikaneni SPR, Adjaye JD, Bakhshi NN. Studies on the catalytic conversion of canola oil to hydrocarbons - influence of hybrid catalysts and steam. Energy Fuels. 1995;9(4):599-609, doi: 10.1021/ef00052a005.

51. Leng TY, Mohamed AR, Bhatia S. Catalytic conversion of palm oil to fuels and chemicals. Canadian J Cheml Eng. 1999;77(1):156-62, doi: 10.1002/cjce.5450770126.

52. Speight JG. Handbook of petroleum product analysis. Hoboken (NJ): John Wiley \& Sons, Inc.; 2002.

53. Swern D. No Title. In: Swern D, editor. Bailey's industrial oils and fat products. 3rd ed. New York (US): Interscience Publishers; 1964. p. 128-131.

54. Ong YK, Bhatia S. The current status and perspectives of biofuel production via catalytic cracking of edible and non-edible oils. Energy. 2010;35(1):111-9, doi: 10.1016/j.energy.2009.09.001. 